\title{
ARTIKELEN
}

\section{Een eerste blik op online delinquentie}

\section{Verkennend onderzoek bij Vlaamse jongeren en vergelijking met offline delinquentie}

Ena Coenen

$\mathrm{Nu}$ het sociale leven van jongeren zich meer en meer online afspeelt, is de aandacht voor cybercriminaliteit gestegen. Echter, hierover zijn in Vlaanderen nog geen cijfers voorhanden. Deze studie gebruikt twee grootschalige, representatieve bevragingen om de prevalentie en risicoprofielen van online dader-en slachtofferschap onder Vlaamse jongeren te onderzoeken. De resultaten tonen aan dat, vergeleken met offline delinquentie, online dader- en slachtofferschap relatief beperkt blijft. Verder werden enkele verschillen gevonden in de risicoprofielen. Daarbij bleek dat daders van enkel online delicten het minst ernstige profiel hadden, en daders van zowel on-als offline vormen het meest ernstige. Voor slachtofferschap kwam een complexer beeld van risicofactoren naar voor, waarbij het van belang lijkt om aandacht te hebben voor specifieke vormen van slachtofferschap. Deze resultaten duiden op een beperkte, maar niet-verwaarloosbare, prevalentie van online delinquentie, waarbij online daders en slachtoffers enkele verschillen vertonen met hun offline tegenhangers.

\section{Inleiding}

Sinds enkele jaren is er in de criminologische wereld meer en meer aandacht voor de opkomst van cybercriminaliteit. Door vooruitgang op het vlak van technologie en media verschuift het leven naar de virtuele ruimte. Smartphones zorgen ervoor dat mensen altijd en overal toegang hebben tot het internet en er bieden zich steeds meer onlinediensten aan. Zeker jongeren gaan mee op deze trend van een uitgebreide online identiteit. Uit een jaarlijkse bevraging van het media- en technologiegebruik van Vlamingen blijkt dat ongeveer 95 procent van de 15- tot 19-jarigen een smartphone heeft (de Digimeter van het Interuniversitair MicroElektronica Centrum (imec); Vanhaeleweyn \& De Marez, 2017). Daarnaast heeft het overgrote merendeel van de jongeren verscheidene socialemedia-accounts, zoals Facebook (84 procent) of Instagram (71 procent), die ze vaak intensief gebruiken.

Met deze verschuiving van een offline naar een online leven bestaat de kans dat ook criminaliteit zich verschuift volgens deze nieuwe ontwikkelingen. Zo kunnen bedreigingen gemakkelijk geuit worden via sociale media of e-mail, kunnen seksueel getinte beelden eenvoudig worden verspreid via deze netwerken, of kan een online profiel gehackt worden. Enkele cijfers uit verschillende Europese landen tonen aan dat cybercriminaliteit aanzienlijk voorkomt onder jongeren (Montiel 
Juan, 2016; Rokven e.a., 2017). Echter, onderzoek naar de prevalentie van deze nieuwe vormen van delinquent gedrag ontbreekt in Vlaanderen. Dit onderzoek zal een eerste blik op online delinquentie onder Vlaamse jongeren bespreken, gebaseerd op een verkennende bevraging via de monitors van het Jeugdonderzoeksplatform (JOP).

\section{Cijfers uit Vlaanderen en Nederland}

Zoals reeds aangehaald, bestaat er op dit moment in Vlaanderen weinig onderzoek naar online delinquentie. Echter, twee onderzoeken hadden reeds aandacht voor het fenomeen. In 2018 publiceerde de imec-Media, Innovatie \& Communicatietechnologie (imec-MICT)-groep een rapport over slachtofferschap van cybercriminaliteit bij volwassenen in België (Martens \& De Wolf, 2018). Zij bevroegen een representatieve steekproef, op leeftijd, geslacht en gewest waarin de respondent woont, over vier types van online criminaliteit: malware, scams (via misleiding informatie of geld verkrijgen), hacken en monitoring (het verzamelen van gegevens van het slachtoffer door een privébedrijf of de overheid) aan de hand van een online survey. Hierbij vonden zij prevalenties van respectievelijk 17, 7, 10 en 13 procent. In 2018 werd een ander rapport gepubliceerd over slachtofferschap van cybercriminaliteit bij Belgische bedrijven (Paoli e.a., 2018). Hieruit bleek dat ongeveer de helft van de bevraagde bedrijven aangaf slachtoffer te zijn geweest in de laatste twaalf maanden van een van de bevraagde delictsvormen. Dit zijn echter, bij mijn weten, de enige rapporten over (slachtofferschap van) online delinquentie in Vlaanderen. Beide bestaande rapporten focussen niet op jongeren, en bespreken enkel slachtofferschap van cybercriminaliteit.

In Nederland is al meer onderzoek gedaan rond cybercriminaliteit. Zo heeft het Wetenschappelijk Onderzoek- en Documentatiecentrum (WODC) verschillende rapporten gepubliceerd die aandacht hebben voor dit thema. Zo vonden Rokven en collega's (2017) dat 28,3 procent van de bevraagde jongeren aangaf in de voorbije twaalf maanden minstens één vorm van online delinquentie te hebben gepleegd. Dit resultaat steunt op een grootschalige bevraging van 12- tot 22-jarige Nederlandse jongeren. Uit individuele delictprevalenties bleek dat enkele delicten vaker werden gerapporteerd dan andere. Inloggen op een computer of account zonder toestemming werd door bijna 15 procent van de jongeren gerapporteerd, terwijl digitale bedreiging rond de 7 procent lag. Het verspreiden van seksueel getint beeldmateriaal van minderjarigen werd nog gerapporteerd door ongeveer 3 procent van de jongeren. Deze prevalenties liggen iets hoger dan in ander Nederlands onderzoek bij jongeren (Zebel e.a., 2013). In dit overzicht bleef de prevalentie van de meeste onderzochte cyberdelicten, zoals online bedreiging en hacken, onder de 5,5 procent.

Onderzoek wijst er verder op dat de meeste online daders ook offline daders zijn (Donner e.a., 2015; Van der Laan e.a., 2016; Weulen Kranenbarg e.a., 2019). Dit lijkt omgekeerd niet te gelden, waarbij de groep die enkel offline delicten pleegt groter is dan de groep die enkel online delicten of beide soorten delicten pleegt (Rokven e.a., 2017).

In Nederland werden ook studies gedaan naar de prevalentie van slachtofferschap van cybercriminaliteit in representatieve steekproeven van de volledige bevolking 
(voor een review van verschillende Europese landen, waaronder Nederland, zie Reep-van den Bergh \& Junger, 2018). Het merendeel van de prevalenties van slachtofferschap bleef, net zoals in de andere landen in de review, relatief laag in Nederland, met cijfers tussen de 0 en 5 procent. Zo lagen de prevalenties voor online bedreiging rond de 0,6 procent in Nederlandse surveys, terwijl slachtofferschap van hacken iets vaker voorkwam, met prevalenties tussen de 3,6 en 5,8 procent. Er waren echter ook uitschieters, zoals een studie waarin de prevalentie voor slachtofferschap van malware opliep tot bijna 15 procent.

Het Centraal Bureau voor Statistiek (CBS, 2019) van Nederland deed in 2018 onderzoek naar slachtofferschap van online delinquentie bij burgers vanaf 12 jaar, en vond dat ongeveer 8,5 procent van hun representatieve steekproef van een of meerdere bevraagde vormen van cybercriminaliteit slachtoffer was geworden in het laatste jaar. Hierbij kwamen online vermogensdelicten het meest voor, met 4,6 procent. Hacken werd minder gerapporteerd, door ongeveer 1,8 procent. Slachtofferschap van online bedreiging werd door 1,4 procent gerapporteerd, wat verder daalde naar 0,7 procent als het seksuele incidenten betrof. Zij vonden tevens dat de jongere groepen (tot 25 jaar) meer kans hadden om slachtoffer te worden dan de oudere groepen in de bevolking.

\section{De verschillende vormen van online delinquentie}

Wanneer online delinquentie wordt onderzocht, wordt een onderscheid gemaakt tussen delinquentie waarbij ICT-structuren het doel zijn (zoals hacken of ddosaanvallen) en delinquentie waarbij ICT slechts een hulpmiddel is (zoals online bedreiging of het verspreiden van seksueel getint beeldmateriaal zonder toestemming). Met andere woorden, ICT-structuren zijn noodzakelijk voor de eerste vorm, terwijl de tweede vorm klassieke, offline delicten zijn die nu worden uitgevoerd met de hulp van informatica. Naar deze eerste vorm wordt verwezen als cybercriminaliteit in de enge zin, en naar de tweede vorm als cybercriminaliteit in de brede zin of gedigitaliseerde criminaliteit (bijv. Zebel e.a., 2013).

Verschillende vormen van online en offline delinquentie kunnen door elkaar lopen. Zo werd gevonden dat hacken, een cyberdelict in de enge zin, vaak verband houdt met andere delictsvormen (Leukefeldt e.a., 2010). Hacken wordt gecombineerd met andere cyberdelicten in de enge zin (bijv. het kopiëren van gegevens), vermogensdelicten (bijv. oplichting of afpersing) of persoonsdelicten (bijv. bedreiging). Hierbij wordt hacken als een middel gebruikt om andere (criminele) doelen te bereiken.

\section{Risicoprofielen cybercriminaliteit}

Er zijn verschillende perspectieven op de verklaringsmechanismen van online delinquentie. Hierin bestaan twee grote lijnen. De eerste lijn stelt dat de verklaringen voor offline delinquentie ook voor online delinquentie werken (Grabosky, 2001). Met andere woorden, risicofactoren die de kans om offline dader te zijn vergroten, vergroten ook de kans om online dader te zijn. Hierbij wordt vooral gefocust op de routineactiviteitentheorie (i.e. gemotiveerde dader, mogelijkheid en weinig externe controle; Cohen \& Felson, 1979) en de zelfcontroletheorie (i.e. lage zelfcontrole; Gottfredson \& Hirschi, 1990). 
Langs de andere kant werd geopperd dat online delinquentie eigen, nieuwe verklaringsmechanismen nodig heeft. Hierbij wordt cybercriminaliteit gezien als een aparte vorm van delinquentie, in een unieke omgeving met eigen sociale normen (Capeller, 2001). Doordat de virtuele omgeving anders is dan de fysieke, kunnen cyberdelicten niet vergeleken worden met klassieke, offline delicten, en ontstaat er een nood aan nieuwe verklaringsmechanismen.

Rokven en collega's (2017) onderzochten, naast de prevalentie van gedigitaliseerde en cybercriminaliteit, ook de profielen van online daders. Hiervoor gebruikten zij klassieke risicofactoren, zoals zelfcontrole en delinquente vrienden. $\mathrm{Zij}$ vonden enkele verschillen in beschermende of risicofactoren bij minderjarigen tussen online daders enerzijds en offline daders of daders van zowel online als offline delicten anderzijds. Zo verkleinden druggebruik en het goedkeuren van offline delinquent gedrag de kans om online dader te zijn ten opzichte van offline of gecombineerde daders. Tevens hadden vrouwen en jongeren van autochtone afkomst een grotere kans om online dader dan offline dader te zijn. In vergelijking met daders die zowel online als offline feiten pleegden, hadden jongeren met minder vrienden die offline of gedigitaliseerd delinquent gedrag stelden en die tevredener zijn met hun school, een hogere kans om online dader te zijn. Dit geeft aan dat er toch enkele verschillen in risicoprofiel te vinden zijn.

Daarnaast bleek dat jongeren die enkel cyberdelicten in de enge zin pleegden het minst risicovolle profiel hadden, vergeleken met daders van offline, gedigitaliseerde of verschillende soorten delicten (Rokven e.a., 2017). Dit kan erop wijzen dat voor deze groep andere factoren relevanter zijn, en dus nieuwe verklaringsmechanismen nodig zijn. Meer digitale risicofactoren, zoals veel gamen en interesse in ICT, lijken een bijkomende invloed te hebben op de kans om cyberdader te zijn (Van der Wagen e.a., 2020). Met andere woorden, alhoewel veel klassieke risicofactoren relevant blijven voor cyberdaders, lijkt er nood te zijn dat enkele persoonlijke en situationele risicofactoren worden afgestemd op de virtuele context (Weulen Kranenbarg, 2018; Van der Wagen e.a., 2020).

Enkele studies onderzochten ook de rol van risicofactoren, zelfcontrole en routineactiviteiten op slachtofferschap van cybercriminaliteit. Oksanen en Keipi (2013) onderzochten slachtofferschap van cybercriminaliteit, waarbij geen onderscheid werd gemaakt tussen enge of brede vormen, bij 15- tot 75-jarigen. Zij vonden dat slachtofferschap hiervan vaker voorkwam bij 15- tot 24-jarigen vergeleken met de oudere groepen. Analyses naar de achtergrondkenmerken van slachtoffers toonden verder aan dat naast leeftijd, ook geslacht, opleidingsniveau, economische status, slachtofferschap van geweld en de frequentie van deelname in online gemeenschappen invloed hadden op de kans cybercriminaliteit mee te maken.

Reyns en collega's (2019) vonden dat opportuniteit slachtofferschap van cybercriminaliteit in de enge en in de brede zin kon voorspellen, maar dat zelfcontrole enkel gerelateerd was aan de kans slachtoffer te zijn van cyberdelicten in de brede zin. De resultaten toonden daarnaast aan dat geslacht een invloed had op de kans slachtoffer te worden van intimidatie (hogere kans) en seksuele of expliciete inhoud te ontvangen (lagere kans), en leeftijd geassocieerd was met een hogere kans om slachtoffer te worden van cyberdelicten in de enge zin. De rol van oppor- 
tuniteit werd ook gevonden in de kans slachtoffer te worden van online intimidatie bij adolescenten (Bossler e.a., 2012). Deze studie vond dat jongeren die meer gebruik maakten van sociale media, vrienden hadden die dader waren van online intimidatie en gevoelige, persoonlijke informatie online plaatsten, een hogere kans hadden slachtoffer te worden. In deze studie was er geen invloed van geslacht op de kans om slachtoffer te worden.

\section{Dit onderzoek}

Dit onderzoek tracht een eerste blik te werpen op cybercriminaliteit onder Vlaamse jongeren. Er wordt naar dader- en naar slachtofferschap gekeken, waarbij zowel algemene prevalenties als risicokenmerken worden onderzocht. De prevalentie van verschillende vormen van online criminaliteit wordt nagegaan in twee grote representatieve steekproeven van Vlaamse jongeren. Hierbij wordt gefocust op één cyberdelict in de enge zin, hacken, en twee cyberdelicten in de brede zin, online bedreiging en het verspreiden van seksueel getint beeldmateriaal zonder toestemming (in de tabellen en figuren verder aangeduid als 'sexting'). Ter vergelijking wordt ook de prevalentie van enkele offline, klassieke vormen van criminaliteit besproken. Hiermee wordt getracht een eerste verkenning van het voorkomen van online delinquentie, naast offline delinquentie, bij Vlaamse jongeren te bekomen.

Voor de risicoprofielen wordt gebruik gemaakt van één representatieve dataset, en wordt gefocust op de twee gedigitaliseerde delicten. Zoals bij de prevalenties wordt hier een vergelijking gemaakt met offline delinquentie. De invloed van een aantal achtergrondkenmerken van daders en slachtoffers, zoals geslacht, leeftijd en onderwijsvorm, wordt onderzocht. Daarnaast werden delinquentie van vrienden (enkel voor daderschap), armoederisico en stedelijke omgeving mee opgenomen. Aangezien zeker een combinatie van risicofactoren zorgt voor een verhoogde kans op daderschap (bijv. Stouthamer-Loeber e.a., 2002), is het belangrijk om te testen of risicofactoren die eerder al een verband toonden met offline delinquentie, dit ook doen voor online vormen van delinquentie. In navolging van vorig onderzoek worden hier enkele verschillen, zoals de invloed van geslacht en delinquentie van vrienden, verwacht (bijv. Rokven e.a., 2017). Ook voor slachtofferschap is het van belang na te gaan of dezelfde jongeren die vaker offline slachtoffer worden, tevens vaker slachtoffer worden van online delicten. Dit deel is in grote mate exploratief. 


\section{Methode $^{1}$}

\section{Participanten}

De JOP-postmonitor is een grootschalige bevraging van de Vlaamse jongeren tussen de 14 en 25 jaar aan de hand van een trekking uit het Rijksregister. ${ }^{2}$ Een gestratificeerde steekproef gebaseerd op leeftijd en gender werd gebruikt. Hierbij werden jongens oversampled om representativiteit te bekomen, aangezien uit de vorige afnames van de JOP-monitors bleek dat deze groep een lagere responsgraad vertoonde (JOP, 2018b). In totaal namen 1.411 respondenten (responsgraad 28,3 procent ${ }^{3}$ ) deel. Deze steekproef werd gecontroleerd op representativiteit op geslacht, leeftijd en onderwijs. Wegingscoëfficiënten werden berekend om kleine afwijkingen te corrigeren (JOP, 2018b).

In de schoolmonitor werd gefocust op grootsteden. Alle Nederlandstalige reguliere middelbare scholen voor dagonderwijs in Antwerpen, Gent en Brussel werden aangeschreven om deel te nemen aan dit onderzoek (JOP, 2018a). Daarnaast werd een gestratificeerde (op basis van graden en onderwijsvorm) vergelijkingsgroep van Vlaamse scholen (niet grootstedelijk) gecreëerd. Uiteindelijk namen 27 scholen uit Antwerpen (44,3 procent), 18 uit Brussel (58,1 procent), 14 uit Gent (41,2 procent) en 21 uit Vlaanderen (53,9 procent) deel aan dit onderzoek (JOP, 2018a). In elke deelnemende school werd at random één klas per jaar en onderwijsvorm getrokken. In totaal werden data verzameld van 8.439 leerlingen. Ook voor deze monitor werden wegingscoëfficiënten berekend. Voor deze studie werden wegingscoëfficiënten gebruikt waarbij de grootstedelijke steekproef wordt afgezet tegen de Vlaamse vergelijkingsgroep. Beide groepen waren representatief. In tabel 1 worden gegevens rond leeftijd, geslacht en onderwijs gegeven van beide steekproeven. De postmonitor heeft een iets oudere doelgroep vergeleken met de schoolmonitor. Alle steekproeven waren ongeveer gelijk verdeeld over de twee geslachten. In elke steekproef kwamen de meeste jongeren uit het algemeen secundair onderwijs (aso) of kunst secundair onderwijs (kso) (tussen de 40 en 50 procent), waarbij ongeveer een vierde tot een derde van de steekproef uit het technisch secundair onderwijs (tso) of uit het (deeltijds) beroepssecundair onderwijs ((d)bso) of het buitengewoon secundair onderwijs (buso) kwam. ${ }^{4}$

1 Voor meer info over de methode, raadpleeg de technische verslagen op de JOP-website. JOPpostmonitor 4 (2018): www.jeugdonderzoeksplatform.be/files/Technisch_verslag_JOPPostmonitor_2018.pdf; JOP-schoolmonitor 2 (2018): www.jeugdonderzoeksplatform.be/files/ Technischverslag_JOP-schoolmonitor_2018.pdf.

2 Het Rijksregister van de natuurlijke personen is een databank van bevolkingsgegevens van alle burgers van België, beheerd door de Federale Overheidsdienst Binnenlandse Zaken.

3 Deze responsgraad verschilt niet substantieel van veel andere postsurveys met vergelijkbare steekproefbenaderingen (zie bijv. Sahlqvist e.a., 2011 voor meer informatie over responsgraden in postsurveyonderzoek).

4 Het Belgische aso komt grotendeels overeen met het Nederlandse vwo, tso met havo-denkniveau en bso met vmbo, alhoewel dit geen een-op-eenrelatie is. 
Tabel 1 Sociodemografische gegevens van de verschillende steekproeven (gemiddelde (SD, range) voor leeftijd, percentage $(N)$ voor geslacht en onderwijsvorm)

\begin{tabular}{llll}
\hline & $\begin{array}{l}\text { Postmonitor } \\
(\mathbf{N}=1.382)\end{array}$ & Schoolmonitor & \\
& & Grootstad (N=4.I0I) & $\begin{array}{l}\text { Vlaanderen } \\
(\mathbf{N}=1.747)\end{array}$ \\
\hline Leeftijd & $19,46(3,46,14-26)$ & $16,31(1,56,9-23)$ & $16,09(1,52,12-2 I)$ \\
Geslacht (vrouw) & $49,4(682)$ & $52,3(2.100)$ & $48,4(827)$ \\
Onderwijsvorm & & & \\
Aso-kso & $43,7(572)$ & $50,4(2.067)$ & $42,0(733)$ \\
Tso & $28, I(368)$ & $23,3(957)$ & $32,2(562)$ \\
Bso-dbso-buso & $28,2(368)$ & $25,3(1.038)$ & $25,4(443)$ \\
\hline
\end{tabular}

Bron: JOP-postmonitor 4 (2018); JOP-schoolmonitor 2, tweede en derde graad (2018)

\section{Vragenlijst}

De vragenlijst van zowel de post- als de schoolmonitor bouwt verder op de vorige edities. Aangezien de JOP-monitors een algemene 'staat van de jeugd' willen bekomen, worden verschillende thema's bevraagd. Voor deze bijdrage zullen enkel de relevante items worden besproken. Verder moet nog opgemerkt worden dat de post- en schoolmonitorvragenlijsten niet volledig gelijk zijn. Enkele thema's en vragen verschillen. Wanneer relevant worden deze hierrond besproken.

Dader- en slachtofferschap komen in beide monitors aan bod. Er werd gevraagd naar de frequentie van specifieke delicten in het afgelopen jaar. Echter, de exact gestelde vragen verschillen. In tabel 2 wordt een overzicht gegeven van de daderschapsvragen. Een vraag (hacken) kwam enkel voor in de postmonitor. In tabel 3 wordt dit overzicht gegeven voor de items rond slachtofferschap. Naast de extra vraag over hacken in de postmonitor, werd voor slachtofferschap het item rond online bedreiging niet gesteld in de postmonitor. Respondenten konden in beide monitors steeds antwoorden met nooit/niet, één keer, twee keer, drie keer of meer dan drie keer. Dit werd omgezet naar dummyvariabelen, waarbij een strikt onderscheid werd gemaakt tussen niet-daders en niet-slachtoffers en jongeren die minstens één keer dader of slachtoffer waren in het afgelopen jaar. De twee vormen van diefstal bij de daderschapsvragen werden samengenomen.

Verder werd informatie rond geslacht, leeftijd, onderwijsvorm, armoederisico en delinquente vrienden gebruikt uit de schoolmonitor voor de risicoprofielen. Voor geslacht moesten de respondenten aanduiden of zij een jongen/man of meisje/ vrouw waren. Leeftijd werd bevraagd door te vragen hoe oud de participant is. De onderwijsvorm werd omgezet in een dummyvariabele, waarbij jongeren uit bso in één groep werden gecategoriseerd, en jongeren uit aso, tso en kso in de andere. Armoederisico werd berekend aan de hand van vier items van de EU-SILC 2017- 
Tabel 2 Items over daderschap in post-en schoolmonitor

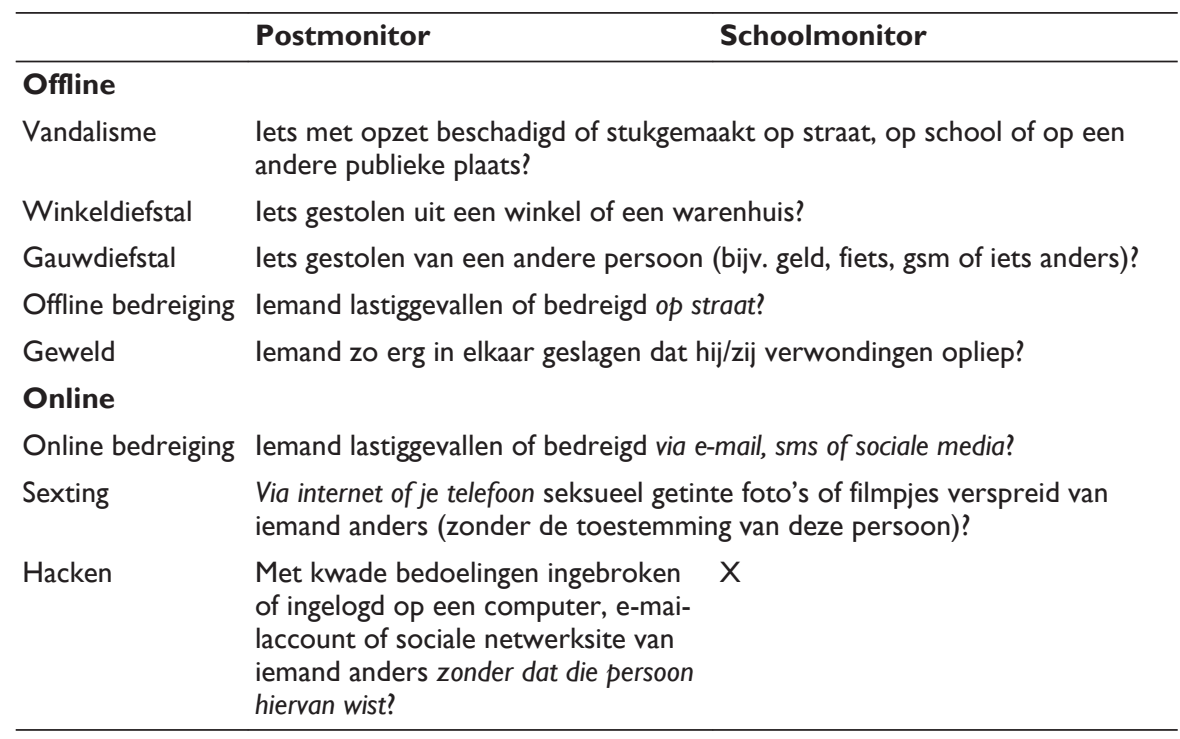

Tabel 3 Items over slachtofferschap in de post-en schoolmonitor

\begin{tabular}{|c|c|c|}
\hline & Postmonitor & Schoolmonitor \\
\hline \multicolumn{3}{|l|}{ Offline } \\
\hline Vandalisme & $\begin{array}{l}\text { Er met opzet iets beschadigd werd } \\
\text { dat van jou was? }\end{array}$ & $\begin{array}{l}\text { Er met opzet iets van jou beschadigd } \\
\text { werd? }\end{array}$ \\
\hline Diefstal & \multicolumn{2}{|c|}{ Er iets van jou gestolen werd (zonder dwang of geweld)? } \\
\hline Offline bedreiging & \multicolumn{2}{|c|}{ Je lastiggevallen of bedreigd werd op straat? } \\
\hline Geweld & \multicolumn{2}{|c|}{$\begin{array}{l}\text { Je in elkaar geslagen werd zodat je er Je geslagen werd zodat je verwondin- } \\
\text { verwondingen aan overhield? }\end{array}$} \\
\hline \multicolumn{3}{|l|}{ Online } \\
\hline Online bedreiging & $x$ & $\begin{array}{l}\text { Je lastiggevallen of bedreigd werd via } \\
\text { e-mail, sms of sociale media? }\end{array}$ \\
\hline Sexting & \multicolumn{2}{|c|}{$\begin{array}{l}\text { Er seksueel getinte foto's of filmpjes van jou online verspreid werden } \\
\text { (zonder jouw toestemming)? }\end{array}$} \\
\hline Hacken & $\begin{array}{l}\text { Er met kwade bedoelingen werd } \\
\text { ingebroken of ingelogd op jouw com- } \\
\text { puter, e-mailaccount, website of pro- } \\
\text { fielsite? }\end{array}$ & $X$ \\
\hline
\end{tabular}

bevraging. Deze items peilden ernaar of het gezin zich de volgende dingen kon veroorloven: (1) de rekeningen op tijd betalen (huur, water, elektriciteit, enz.), (2) een grote, onverwachte uitgave doen, (3) elk jaar een week ergens op vakantie gaan, en (4) het huis/appartement voldoende verwarmen. Indien de jongere hier twee of meer keer negatief op antwoordde, werd deze jongere beschouwd als een jongere uit een gezin met een verhoogd armoederisico. Tot slot werd offline delin- 
quentie van vrienden bevraagd aan de hand van vier vragen die peilden naar winkeldiefstal, gauwdiefstal, vandalisme en geweld, waarbij de jongere moest aangeven hoeveel van zijn/haar vrienden dit wel eens deden (vierpuntenschaal van 1 (geen enkele) tot 4 (allemaal)). Deze items werden samengenomen in een schaal voor de analyses.

\section{Procedure}

Nadat de steekproef was getrokken voor de JOP-postmonitor werden respondenten in totaal vijf keer aangeschreven, indien nog geen respons was ontvangen. De eerste wave werd verstuurd op 24 januari 2018 en de laatste op 25 april 2018. In de eerste drie waves was het enkel mogelijk om de opgestuurde vragenlijst in te vullen. Vanaf de vierde wave werd ook een onlineversie van de vragenlijst voorzien, in de hoop de responsgraad te verhogen. Respondenten konden vragenlijsten terugsturen tot 31 mei 2018.

In tegenstelling tot de JOP-postmonitor verliepen de afnames van de JOP-schoolmonitor in hoofdzaak via tablets. De vragen konden door het gebruik van tablets in verschillende volgordes worden aangeboden aan de respondenten. Op deze manier werd getracht om de itemnon-respons beter te verdelen (aangezien de laatste vragen, die meer kans hebben niet ingevuld te worden, nu varieerden). Ouders konden de deelname van hun kind weigeren via een opt-outstrookje. Ook de leerlingen zelf konden weigeren deel te nemen aan het onderzoek. Elke afname in de scholen werd begeleid door minstens twee onderzoekers, en voor de afname werd uitleg gegeven over de inhoud en het doel van het onderzoek. Leerlingen werden erop gewezen dat ze niet verplicht waren om deel te nemen, en als ze deelnamen ook niet verplicht waren om elke vraag in te vullen.

\section{Data-analyse}

Voor de prevalenties wordt gebruik gemaakt van beide datasets. Verschillen in de schoolmonitor tussen de jongeren uit de grootstedelijke en Vlaamse vergelijkingsgroep werden berekend aan de hand van chikwadraattoetsen. Vergelijkingen tussen de postmonitor en schoolmonitor zijn niet gedaan, aangezien deze twee monitors een verschillende doelgroep en methode hebben. Om de informatie op een overzichtelijke manier aan te kunnen bieden, worden deze wel in dezelfde figuren en tabellen besproken, maar een vergelijking tussen deze twee is op dit moment niet mogelijk. Om de profielen te testen werd enkel gebruik gemaakt van de JOP-schoolmonitor 2 (2018), tweede en derde graad. De eerste graad werd buiten beschouwing gehouden, aangezien zij een ingekorte versie van de vragenlijst kregen. Risicoprofielen werden berekend aan de hand van multinomiale logistische regressies. Hierbij werden steeds enkel offline, enkel online, of beide soorten daders of slachtoffers vergeleken met niet-daders en -slachtoffers. Significantie wordt steeds berekend aan de hand van de p-waarde, met als cut-off .05. Voor de risicoprofielen wordt verder gefocust op de odds ratio en hun betrouwbaarheidsinterval van 95 procent. Voor de leesbaarheid worden in de tekst enkel significante effecten besproken. 


\section{Resultaten}

\section{Prevalenties daderschap}

In figuur 1 worden de prevalenties van zelfgerapporteerd daderschap over de verschillende delictsvormen in de afgelopen twaalf maanden weergegeven voor de post- en schoolmonitor. Uit figuur 1 blijkt dat het aangegeven daderschap van online delinquentie beperkt blijft in de postmonitor. Hacken heeft een prevalentie van 3,3 procent, het verspreiden van seksueel getint beeldmateriaal zonder toestemming 3,4 procent en online bedreiging 4,8 procent. In deze steekproef komen enkele klassiekere, offline vormen van delinquentie vaker voor, zoals diefstal (15,1 procent) en vandalisme (11,3 procent). Geweld (4,1 procent) blijkt daarentegen minder vaak voor te komen. Opvallend is dat online bedreiging een hogere prevalentie kent dan offline bedreiging ( 4,8 versus 1,5 procent).

In de schoolmonitor ${ }^{5}$ wordt daderschap van online bedreiging aangegeven door ongeveer 13 procent van de jongeren. Het verspreiden van seksueel getint beeldmateriaal van iemand anders zonder toestemming wordt aangegeven door 6,7 procent van de jongeren in grootsteden en 11,2 procent van de jongeren in Vlaanderen. ${ }^{6}$ Net zoals in de postmonitor wordt daderschap van online bedreiging meer gerapporteerd dan daderschap van offline bedreiging (rond de 13 en 7 procent, respectievelijk). Enkele andere offline vormen van daderschap komen vaker voor, zoals diefstal (rond de 25 procent) en vandalisme (tussen de 20 en 25 procent ${ }^{7}$ ). Geweld komt wat minder vaak voor, met een prevalentie rond de 8 procent. ${ }^{8}$

Wanneer wordt gekeken naar de algemene daderschapsprevalenties (zie tabel 4), kan opgemerkt worden dat online delinquentie minder wordt aangegeven dan offline delinquentie. Zowel in de post- als in de schoolmonitor geeft een beduidend groter deel van de jongeren aan offline delicten te hebben gepleegd in de afgelopen twaalf maanden dan online delicten. Daarenboven blijkt dat het aandeel jongeren dat enkel aangeeft offline delicten te plegen groter is dan het aandeel jongeren dat aangeeft enkel online delicten of een combinatie van beide te plegen.

\section{Prevalenties slachtofferschap}

Als we dezelfde prevalenties voor slachtofferschap beschouwen (zie figuur 2), verkrijgen we een grotendeels gelijkaardig beeld. In de postmonitor zijn de prevalenties van de online delictsvormen 2,2 procent voor het ongewenst verspreiden van seksueel getinte foto's of filmpjes en 9,1 procent voor het kwaadwillig inbre-

5 Significante verschillen tussen de grootstedelijke en Vlaamse steekproef worden in een voetnoot aangeduid.

$6 \quad \chi_{1}=33,588 ; \mathrm{p}<.001 ; \mathrm{N}=5.591$.

722,5 procent in de grootsteden, 25,5 procent in de Vlaamse vergelijkingsgroep $\chi_{1}=5,911 ; \mathrm{p}=.015$; $\mathrm{N}=5.590$.

88,9 procent in de grootsteden, 7,1 procent in de Vlaamse vergelijkingsgroep; $\chi_{1}=4,687 ; \mathrm{p}=.030$; $\mathrm{N}=5.589$. 


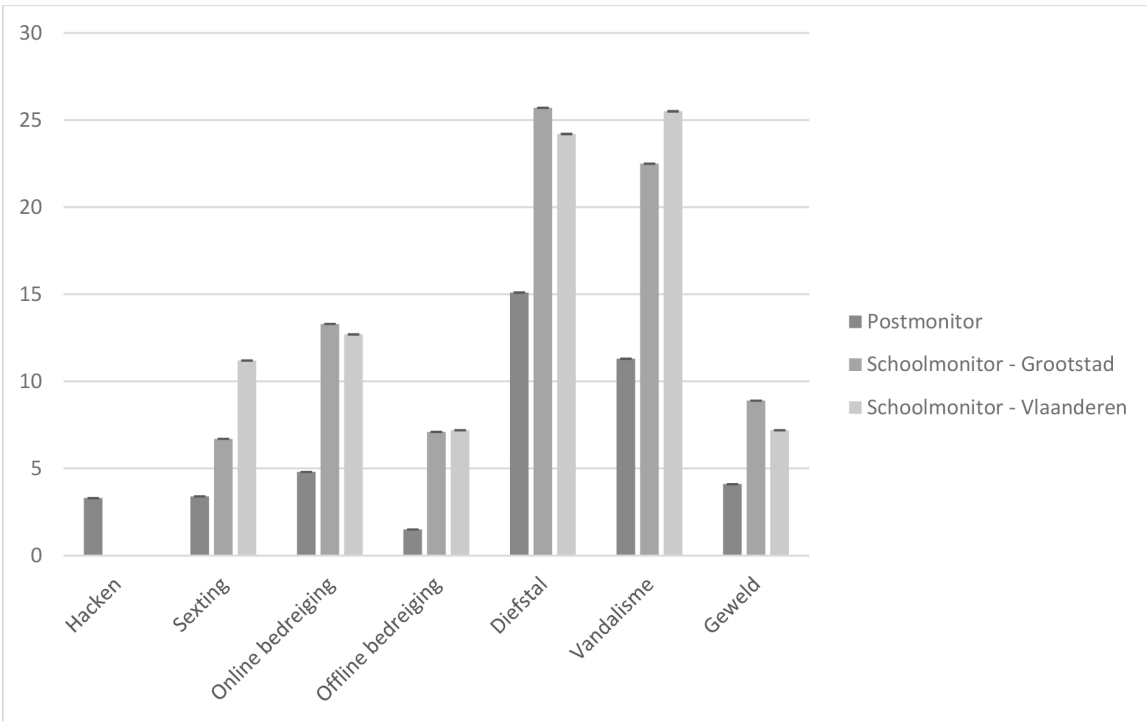

Figuur 1 Prevalentie daderschap verschillende delictsvormen, eerste drie online delicten (in percentages) (bron: JOP-postmonitor 4 (2018); JOPschoolmonitor 2, tweede en derde graad (2018))

Tabel 4 Algemene prevalenties daderschap verschillende delictsvormen en totaal (in percentages)

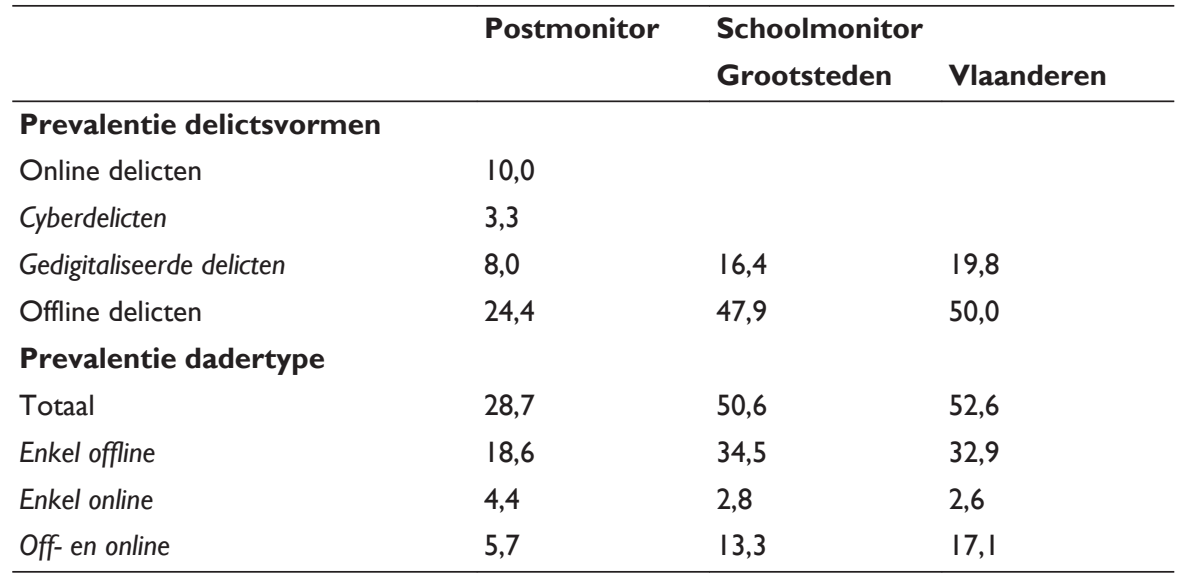

Bron: JOP-postmonitor 4 (2018); JOP-schoolmonitor 2, tweede en derde graad (2018)

ken op een computer of online account. Offline delinquentie wordt vaker aangegeven, waarbij voor zowel offline bedreiging als diefstal het slachtofferschap rond de 25 procent ligt. Vandalisme komt iets minder vaak voor, met een prevalentie van 17,6 procent, en slachtofferschap van geweld wordt aangegeven door 3,8 procent. 


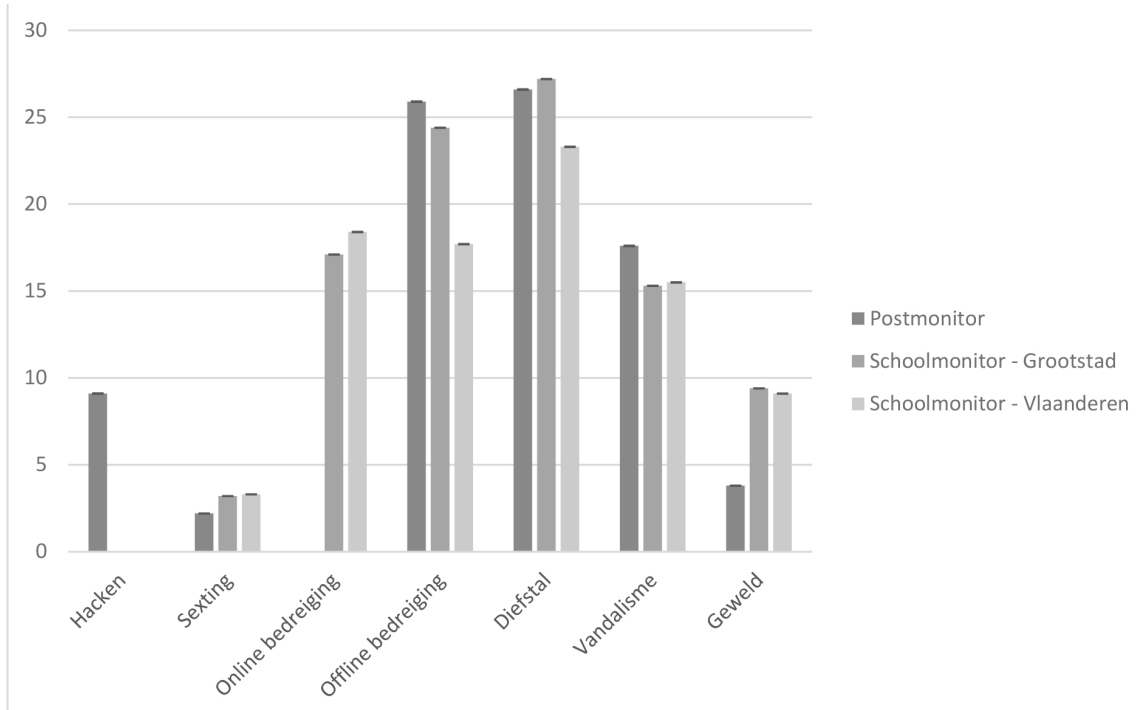

Figuur 2 Prevalentie slachtofferschap verschillende delictsvormen, eerste drie items online delicten (in percentages) (bron: JOP-postmonitor 4 (2018); JOP-schoolmonitor 2, tweede en derde graad (2018))

In de schoolmonitor wordt slachtofferschap van het zonder toestemming verspreiden van seksueel getint beeldmateriaal gerapporteerd door 3,2 procent en online bedreiging door ongeveer 18 procent. Hiermee wordt slachtofferschap van online bedreiging meer aangegeven dan slachtofferschap van vandalisme (15 procent), maar blijft dit nog wel lager dan offline bedreiging en diefstal (rond de 20 à 25 procent $^{9}$ ). Slachtofferschap van geweld komt iets minder vaak voor (rond de 9 procent).

Uit de algemene slachtofferschapsprevalenties kunnen we afleiden dat slachtofferschap van offline delinquentie vaker voorkomt dan online delinquentie (zie tabel 5). Terwijl 15 tot 20 procent van de jongeren aangeeft slachtoffer te zijn geweest van minstens één online delictsvorm in de afgelopen twaalf maanden, geeft ongeveer de helft van de jongeren slachtofferschap van offline delicten aan in diezelfde periode. Ook hier blijkt de groep die enkel slachtoffer werd van een offline delict veel groter dan de groepen die enkel slachtoffer waren van een online delict of die slachtoffer werden van beide types.

9 Bedreiging: 24,4 procent in de grootsteden, 17,7 procent in de Vlaamse vergelijkingsgroep; $\chi_{1}=30,527 ; \mathrm{p}<.001 ; \mathrm{N}=5.595$. Diefstal: 27,2 procent in de grootsteden, 23,3 procent in de Vlaamse vergelijkingsgroep; $\chi_{1}=9,518 ; \mathrm{p}=.002 ; \mathrm{N}=5.702$. 
Tabel 5 Algemene prevalenties slachtofferschap verschillende delictsvormen en totaal (in percentages)

\begin{tabular}{|c|c|c|c|}
\hline & \multirow[t]{2}{*}{ Postmonitor } & \multicolumn{2}{|c|}{ Schoolmonitor } \\
\hline & & Grootsteden & Vlaanderen \\
\hline \multicolumn{4}{|c|}{ Prevalentie delictsvormen } \\
\hline Online delicten & 14,9 & & \\
\hline Cyberdelicten & 9,1 & & \\
\hline Gedigitaliseerde delicten & 7,7 & 18,3 & 19,6 \\
\hline Offline delicten & 53,7 & 51,8 & 47,0 \\
\hline \multicolumn{4}{|c|}{ Prevalentie dadertype } \\
\hline Totaal & 56,2 & 56,1 & 52,9 \\
\hline Enkel offline & $4 I, 6$ & 37,9 & 33,4 \\
\hline Enkel online & 2,7 & 4,2 & 5,8 \\
\hline Off- en online & 12,0 & 14,0 & 13,7 \\
\hline
\end{tabular}

Bron: JOP-postmonitor 4 (2018); JOP-schoolmonitor 2, tweede en derde graad (2018)

\section{Risicoprofielen}

$\mathrm{Na}$ een overzicht van de prevalenties van online en offline delinquentie werden enkele klassieke risicokenmerken van delinquentie bekeken. Hiervoor werden multinomiale logistische regressies voor de algemene prevalenties van enkel online, enkel offline en beide soorten delinquentie uitgevoerd. Voor deze analyses werden enkel de data van de JOP-schoolmonitor 2 (2018) gebruikt, aangezien deze monitor een grotere steekproef had en meer daders van off- en online delicten bevatte.

Zoals kan gezien worden in figuur 3 lijken er enkel verschillen te zijn tussen de daderprofielen. Zo valt op dat, buiten armoederisico dat voor geen enkele groep significant was, alle factoren de kans op de combinatie van online en offline delicten beïnvloedden. Van deze zes factoren waren twee enkel significant voor deze groep: jongeren die schoollopen in bso en jongeren die schoollopen in de rest van Vlaanderen in plaats van een grootstad hadden meer kans om daderschap van online en offline delicten aan te geven. Drie factoren hadden een invloed op zowel gecombineerd daderschap als daderschap van offline delicten, namelijk geslacht, leeftijd en slachtofferschap van offline delicten. Hierbij verkleint de kans om deze soorten daderschap aan te geven bij vrouwen, oudere adolescenten en adolescenten die geen slachtoffer zijn geworden van offline delicten. De laatste factor, offline delinquentie van vrienden, verhoogde de kans op alle soorten daderschap, en is daarmee de enige significante voorspeller van online daderschap.

Wanneer naar de risicokenmerken wordt gekeken voor slachtofferschap, valt op dat minder variabelen de kans om slachtoffer te zijn beïnvloeden (zie figuur 4). Ook hier kende slachtofferschap van beide soorten delicten de meeste voorspellers. Vrouwelijke adolescenten, jongere adolescenten en adolescenten die uit een gezin komen met een verhoogd armoederisico hadden een hogere kans om slacht- 


\begin{tabular}{lc}
\hline & Odds ratio $(95 \%$ CI \\
\hline Vrouw & \\
Offline & $0,66(0,59-0,76)^{*}$ \\
Online & $1,12(0,78-1,61)$ \\
Beide & $0,75(0,62-0,91)^{*}$ \\
Leeftijd & \\
Offline & $0,92(0,87-0,96)^{*}$ \\
Online & $1,11(0,99-1,25)$ \\
Beide & $0,85(0,80-0,91)^{*}$ \\
Bso & \\
Offline & $1,06(0,89-1,25)$ \\
Online & $1,46(0,99-1,25)$ \\
Beide & $1,38(1,10-1,73)^{*}$ \\
Armoederisico \\
Offline & $1,17(0,95-1,44)$ \\
Online & $1,32(0,81-2,18)$ \\
Beide & $1,24(0,93-1,65)$ \\
Grootstad & \\
Offline & $0,96(0,83-1,12)$ \\
Online & $0,83(0,57-1,21)$ \\
Beide & $0,61(0,50-0,74)^{*}$ \\
Offline delinquente vrienden \\
Offline & $1,59(1,52-1,65)^{*}$ \\
Online & $1,29(1,16-1,43)^{*}$ \\
Beide & $1,99(1,89-2,09)^{*}$ \\
Offline slachtofferschap \\
Offline & $1,79(1,55-2,05)^{*}$ \\
Online & $1,04(0,71-1,52)$ \\
Beide & $1,23(1,01-1,50)^{*}$ \\
\hline p<.05 & \\
\hline
\end{tabular}

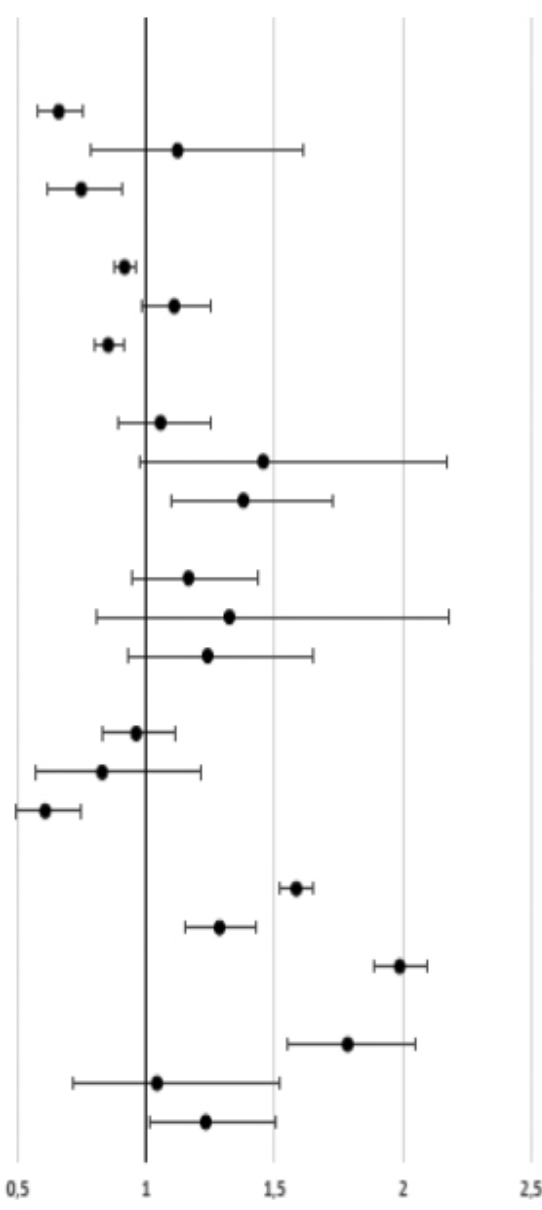

Figuur 3 Risicokenmerken voor algemeen daderschap van enkel offline $(N=1.692)$, enkel online $(N=133)$ en beide soorten $(N=683)$ delicten (versus geen dader, $N=2.419)$ (bron: JOP-schoolmonitor 2, tweede en derde graad (2018))

offerschap van zowel on- als offline delicten te ervaren. Deze laatste factor was voorts de enige significante voorspeller om tot de enkel offline slachtofferschapgroep te behoren, alhoewel minder sterk dan voor gecombineerd slachtofferschap. Slachtofferschap van online delinquentie werd dan weer voorspeld door geslacht, net zoals bij gecombineerd slachtofferschap, en schoollopen in een grootstad of niet, waarbij grootstedelijke jeugd minder kans heeft dit te ondervinden.

Het enige delict waarvan zowel een online als een offline variant bevraagd is, is lastigvallen of bedreiging. Voor dit delict werden dan ook aparte multinomiale 


\begin{tabular}{ll}
\hline & Odds ratio $(\mathbf{9 5} \% \mathbf{C I})$ \\
\hline Vrouw & \\
Offline & $0,95(0,84-1,07)$ \\
Online & $1,52(1,15-2,01)^{*}$ \\
Beide & $1,34(1,13-1,59)^{*}$ \\
Leeftijd & \\
Offline & $1,02(0,97-1,06)$ \\
Online & $0,96(0,88-1,05)$ \\
Beide & $0,92(0,86-0,97)^{*}$ \\
Bso & \\
Offline & $0,86(0,73-1,00)$ \\
Online & $1,33(0,98-1,81)$ \\
Beide & $1,15(0,94-1,40$ \\
Armoederisico & \\
Offline & $1,38(1,14-1,67)^{*}$ \\
Online & $1,12(0,74-1,70)$ \\
Beide & $2,19(1,75-2,75)^{*}$ \\
Grootstad & \\
Offline & $1,10(0,96-1,26)$ \\
Online & $0,73(0,55-0,97)^{*}$ \\
Beide & $0,96(0,80-1,15)$ \\
\hline * p 05 &
\end{tabular}

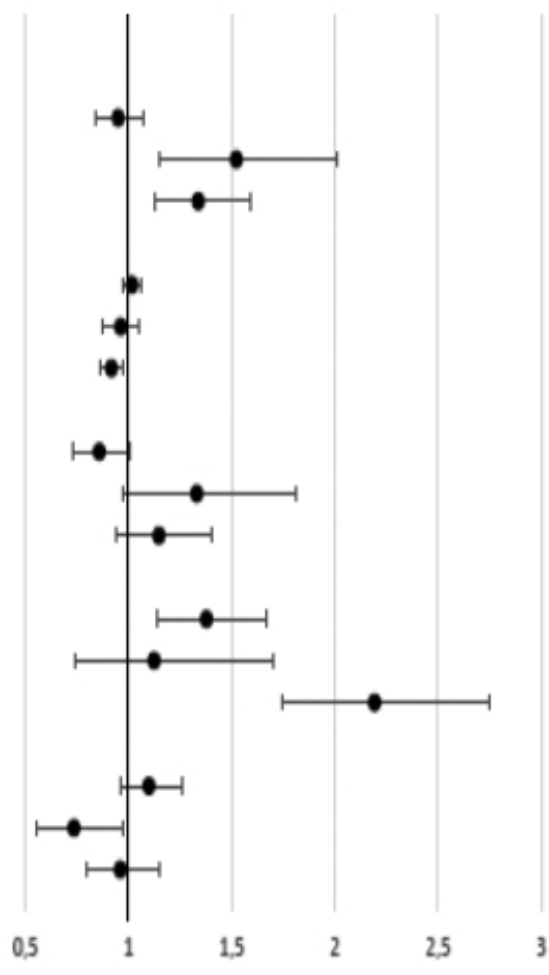

Figuur 4 Risicokenmerken voor algemeen slachtofferschap van enkel offline $(N=1.880)$, enkel online $(N=243)$ en beide soorten $(N=717)$ delicten (versus geen slachtoffer, $N=2.289$ ) (bron: JOP-schoolmonitor 2, tweede en derde graad (2018))

logistische regressieanalyses gedaan om op specifiek delictsniveau te zoeken naar verschillen in risicokenmerken tussen de online- en offlineversie. Voor daderschap (zie figuur 5) zien we dat onderwijsvorm, delinquentie van vrienden en slachtofferschap van offline delinquentie alle vormen van daderschap van bedreiging konden voorspellen. Jongeren die schoollopen in het bso en jongeren die meer offline delinquentie van vrienden rapporteren, hebben een hogere kans op enkel offline, enkel online of beide vormen van daderschap. Jongeren die slachtoffer zijn geweest van een offline delict hadden een hogere kans om daderschap van offline bedreiging te rapporteren, maar een lagere om daderschap van online of beide soorten bedreiging te rapporteren. Offline daderschap en gecombineerd daderschap werden tevens voorspeld door geslacht, waarbij mannen een hogere kans hadden om dit aan te geven dan vrouwen. Tot slot was het schoollopen in de rest van Vlaanderen versus een grootstad enkel significant voor de combinatie van offline en online bedreiging. 


\begin{tabular}{lc}
\hline & Odds ratio $(95 \%$ CI $)$ \\
\hline Vrouw & \\
Offline & $0,31(0,20-0,48)^{*}$ \\
Online & $0,97(0,79-1,20)$ \\
Beide & $0,55(0,40-0,77)^{*}$ \\
Leeftijd & \\
Offline & $1,03(0,91-1,16)$ \\
Online & $0,95(0,89-1,02)$ \\
Beide & $0,96(0,87-1,06)$ \\
Bso & \\
Offline & $1,97(1,31-2,94)^{*}$ \\
Online & $1,54(1,22-1,95)^{*}$ \\
Beide & $1,85(1,32-2,58)^{*}$ \\
Armoederisico \\
Offline & $1,00(0,56-1,77)$ \\
Online & $1,26(0,94-1,69)$ \\
Beide & $1,01(0,64-1,61)$ \\
Grootstad & \\
Offline & $1,46(0,93-2,27)$ \\
Online & $1,02(0,81-1,28)$ \\
Beide & $0,67(0,49-0,93)^{*}$ \\
Offline delinquente vrienden \\
Offline & $1,35(1,26-1,44)^{*}$ \\
Online & $1,29(1,23-1,34)^{*}$ \\
Beide & $1,59(1,51-1,67)^{*}$ \\
Offline slachtofferschap \\
Offline & $1,72(1,19-2,49)^{*}$ \\
Online & $0,78(0,63-0,97)^{*}$ \\
Beide & $0,65(0,47-0,91)^{*}$ \\
\hline p $<.05$ & \\
\hline
\end{tabular}

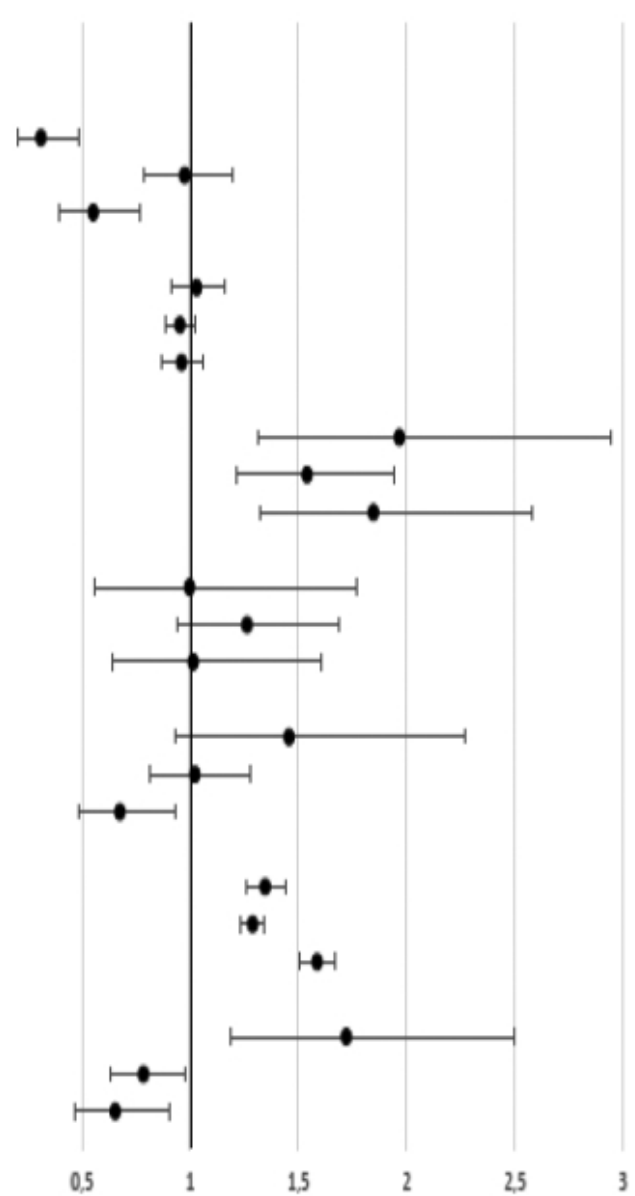

Figuur 5 Risicokenmerken voor daderschap van enkel offline ( $N=122)$, enkel online $(N=420)$ en beide soorten $(N=202)$ bedreiging (versus geen dader, $N=4$.222) (bron: JOP-schoolmonitor 2, tweede en derde graad (2018))

De resultaten voor slachtofferschap van bedreiging zijn terug te vinden in figuur 6. Hierbij valt op dat gecombineerd slachtofferschap nu het kleinste aantal significante voorspellers had, en dat veel voorspellers omgekeerde effecten hadden naargelang type slachtofferschap. Vrouwen en jongeren uit een gezin met verhoogd armoederisico hadden meer kans op alle vormen van slachtofferschap. Ook het schoollopen in een grootstad versus de rest van Vlaanderen was significant voor alle types slachtoffer. Voor slachtofferschap van offline bedreiging of voor de combinatie van offline en online bedreiging was deze kans hoger in de grootsteden, maar voor online bedreiging was deze kans was hoger in de rest van Vlaanderen. Onderwijsvorm en leeftijd voorspelden daarenboven de kans om slachtoffer 


\begin{tabular}{ll}
\hline & Odds ratio $(95 \%$ CI $)$ \\
\hline Vrouw & \\
Offline & $2,04(1,73-2,40)^{*}$ \\
Online & $1,33(1,10-1,61)^{*}$ \\
Beide & $1,81(1,47-2,23)^{*}$ \\
Leeftijd & \\
Offline & $1,19(1,13-1,25)^{*}$ \\
Online & $0,88(0,82-0,94)^{*}$ \\
Beide & $1,05(0,98-1,13)$ \\
Bso & \\
Offline & $0,79(0,65-0,96)^{*}$ \\
Online & $1,29(1,04-1,61)^{*}$ \\
Beide & $0,96(0,75-1,23)$ \\
Armoederisico \\
Offline & $1,31(1,04-1,66)^{*}$ \\
Online & $1,81(1,39-2,35)^{*}$ \\
Beide & $2,26(1,74-2,93)^{*}$ \\
Grootstad & \\
Offline & $1,46(1,22-1,76)^{*}$ \\
Online & $0,78(0,64-0,95)^{*}$ \\
Beide & $1,30(1,03-1,64)^{*}$ \\
\hline p & \\
\hline &
\end{tabular}

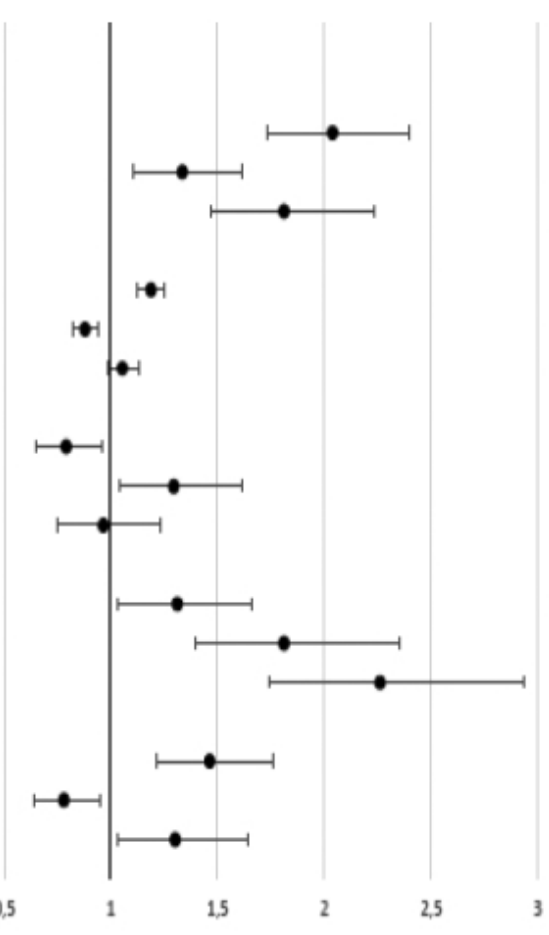

Figuur 6 Risicokenmerken voor slachtofferschap van enkel offline ( $N=760)$, enkel online ( $N=503)$ en beide soorten $(N=420)$ bedreiging (versus geen slachtoffer, $N=3.569)$ (bron: JOP-schoolmonitor 2, tweede en derde graad (2018))

te zijn van enkel offline of enkel online bedreiging. Hierbij hadden oudere jongeren en jongeren die geen les volgen in het bso meer kans om slachtoffer te zijn van enkel offline bedreiging, terwijl jongere jongeren en jongeren die wel bso volgen meer kans hadden om slachtoffer te zijn van online bedreiging.

\section{Discussie en conclusie}

Dit onderzoek wierp een eerste blik op het voorkomen van cybercriminaliteit onder jongeren in Vlaanderen. Hierbij werd zowel daderschap als slachtofferschap onderzocht, en prevalenties en risicoprofielen. Om prevalenties na te gaan werd gebruik gemaakt van twee grootschalige, representatieve bevragingen van Vlaamse jongeren, een post- en een schoolbevraging. De analyses rond risicoprofielen werden gebaseerd op de schoolbevraging. Hierbij werd gevonden dat daderschap en slachtofferschap van online delicten, vergeleken met offline, door een 
kleiner, maar niet verwaarloosbaar, deel van de Vlaamse jongeren werden gerapporteerd. Bij de risicoprofielen kwamen enkele verschillen tussen online, offline en beide vormen van daderschap en slachtofferschap naar voor.

\section{Prevalentie}

Daderschap van cybercriminaliteit blijft relatief beperkt in vergelijking met offline delicten. Online daderschap wordt gerapporteerd door 10 tot 20 procent van de bevraagde jongeren in de verschillende steekproeven, terwijl offline daderschap varieert tussen 24 en 50 procent. De prevalentie van online daderschap ligt in dit onderzoek lager dan in de studie van Rokven en collega's (2017). Dit kan echter liggen aan het feit dat zij meer online delictsvormen hebben bevraagd. De prevalenties van de verschillende delicten afzonderlijk tonen een genuanceerder beeld. Het valt op dat de prevalentie van online bedreiging hoger is dan haar offline tegenhanger, in tegenstelling tot de algemene prevalenties waarbij online delicten minder vaak lijken voor te komen dan offline delicten. Dit kan eventueel verklaard worden doordat online vormen van bedreiging gemakkelijker te uiten zijn dan offline. Door verschillen in steekproeftrekking of vraagstelling is het niet mogelijk om deze prevalenties te vergelijken met ander onderzoek. Verschillen ten opzichte van de besproken literatuur moeten dus voorzichtig geïnterpreteerd worden. Tot slot bleek uit de prevalenties tevens dat daderschap van enkel online delicten minder vaak voorkomt dan daderschap van offline of beide soorten delicten. Deze bevinding komt overeen met resultaten uit andere studies (bijv. Donner e.a., 2015; Rokven e.a., 2017).

Een opvallende bevinding is dat daderschap van de verspreiding van seksueel getint beeldmateriaal zonder toestemming meer aangegeven wordt in de rest van Vlaanderen dan in de drie grootsteden in de schoolmonitor. Helaas werd hiervoor geen verklaring gevonden in de literatuur. Een mogelijke verklaring is dat jongeren in de rest van Vlaanderen een andere vrijetijdsbesteding hebben, waarbij zij vaker online zijn dan jongeren in grootsteden door gebrek aan real-life mogelijkheden. Verder onderzoek zou hier meer duidelijkheid in kunnen scheppen.

Tussen de twee monitors zitten grote verschillen in zelfgerapporteerd daderschap. Daderschap, zowel online als offline, wordt beduidend meer gerapporteerd in de schoolmonitor dan in de postmonitor, gelijkaardig aan vorige bevindingen (Cops, 2014). Dit heeft waarschijnlijk te maken met aspecten van het design. De schoolmonitor bereikt meer jongeren die vaak uitvallen in postenquêtes, zoals jongeren met lagere sociaaleconomische status of met een migratieachtergrond. Alhoewel de representativiteit van de steekproeven op het vlak van geslacht, leeftijd en onderwijsvorm wordt gecontroleerd, is het mogelijk dat ze op andere vlakken verschillen. Omdat de postenquête gevoeliger is voor uitval, is het mogelijk dat jongeren die hierop reageren een lager delinquentieniveau hebben dan hun niet-deelnemende leeftijdsgenoten. Zo vonden ook Beerthuizen en collega's (2018) dat jongeren in hun online en offline steekproef verschilden op een aantal kenmerken, zoals sociodemografische gegevens en delinquentieniveau. Alhoewel zij focusten op invloed van online versus offline bevragingen, zaten er grote verschillen in hoe de twee steekproeven werden benaderd, wat een alternatieve verklaring is voor hun resultaten. Hun online steekproefbenadering lijkt daarbij 
veel meer op de JOP-postenquête dan hun intensievere offline steekproefbenadering, waardoor dezelfde afwijkingen in hun online bevraging en de JOP-postmonitor kunnen bestaan. Daarenboven is de responsgraad van hun online steekproef vergelijkbaar met de responsgraad van de JOP-postenquête, wat verder insinueert dat steekproefbenadering een belangrijke factor is. Naast deze verschillen in bereikte steekproef, wordt in de JOP-postmonitor een oudere groep bevraagd, die zich verder bevindt op de age-crime curve en waarvan het delinquent gedrag al afneemt. Dit versterkt het verschil tussen de twee steekproeven. Echter, aangezien hacken, en bij uitbereiding cybercriminaliteit in de enge zin, enkel in de postmonitor is bevraagd, maar de schoolmonitor een grotere steekproef kent met meer maatschappelijk kwetsbare jongeren, werd ervoor geopteerd om beide monitors te bespreken in dit overzicht.

Gelijkaardig aan daderschap lijkt slachtofferschap van online delicten minder vaak voor te komen dan slachtofferschap van offline delicten. Terwijl ongeveer de helft van de jongeren aangeeft het laatste jaar offline slachtoffer te zijn geworden, is slechts een op vijf tot een op zes slachtoffer geweest van een online delict. Net zoals bij daderschap is dit verschil iets genuanceerder wanneer naar de afzonderlijke delicten wordt gekeken. Zo bleef slachtofferschap van de verspreiding van seksueel getint beeldmateriaal beperkt tot ongeveer 3 procent, maar gaf ruim 17 procent aan slachtoffer te zijn geweest van online bedreiging. In vergelijking met vorig onderzoek zijn dit hoge prevalenties (CBS, 2019; Reep-van den Bergh \& Junger, 2018). Echter, door verschillen in steekproef en vraagstelling moet voorzichtig worden omgegaan met deze vergelijking. De prevalentie van online bedreiging blijft lager dan slachtofferschap van offline bedreiging, waarvan ongeveer een op vier jongeren slachtoffer werd. Zoals bij daderschap komt slachtofferschap van enkel online delicten het minste voor, gevolgd door slachtofferschap van beide vormen en tot slot slachtofferschap van enkel offline delicten, wat het meeste voorkomt.

\section{Risicoprofielen}

Wanneer wordt gekeken naar risicofactoren voor daderschap worden enkele verschillen gevonden tussen online en offline daders. Veel van de onderzochte factoren leken geen invloed te hebben op de kans om uitsluitend online dader te zijn, terwijl deze wel daderschap van offline of beide soorten delicten kon voorspellen. Net zoals in vorig onderzoek (Rokven e.a., 2017) bleken daders van zowel traditionele als gedigitaliseerde delicten de meeste voorspellers te hebben, waarbij zes van de zeven gemeten risicofactoren een significante invloed hadden. Uitsluitend online daderschap werd daarentegen slechts door één factor voorspeld, namelijk offline delinquentie van vrienden. Meer offline delinquentie bij vrienden verhoogde namelijk de kans op elke vorm van daderschap. Hierbij bleek dat deze invloed het grootst was wanneer er overlap was tussen het bevraagde delicttype van vrienden en respondent. Met andere woorden, offline delinquentie van vrienden vertoonde een groter verband met de kans op offline daderschap en daderschap van beide soorten delinquentie dan op online daderschap. Online daderschap van vrienden werd niet bevraagd, waardoor niet kon worden nagegaan of dit meer invloed heeft op de kans online delicten te plegen dan offline delicten, 
alhoewel vorig onderzoek aantoonde dat enkele risicofactoren beter afgestemd zouden moeten worden op de online context (Weulen Kranenbarg, 2018; Van der Wagen e.a., 2020). Dit resultaat ligt verder in de lijn van de resultaten van Rokven en collega's (2017), die vonden dat online daders minder vrienden hadden die offline delicten pleegden vergeleken met daders van on- en offline delicten.

Uit deze bevindingen kan geconcludeerd worden dat enkele klassieke risicofactoren geen invloed lijken te hebben op de kans om online dader te zijn. Net zoals in vorig onderzoek (Rokven e.a., 2017) hebben daders van enkel online delicten een minder ernstig profiel. Deze resultaten kunnen erop wijzen dat andere factoren een belangrijkere rol spelen in de verklaring van gedigitaliseerd daderschap of dat risicofactoren meer moeten worden afgestemd op de virtuele context, zoals gevonden bij cyberdaders (Weulen Kranenbarg, 2018; Van der Wagen e.a., 2020). Een kleine groep daders, die enkel online delinquentie vertonen, heeft nood aan een andere aanpak. Klassieke risicofactoren lijken hier minder een rol te spelen, waardoor ook pre- en interventies voor deze groep minder effectief kunnen zijn. Verder onderzoek is nodig om deze groep te doorgronden. Daders van beide soorten hadden het meest uitgesproken profiel, wat overeenkomt met voorgaand onderzoek (Rokven e.a., 2017).

Er werden eveneens enkele verschillen in risicoprofiel tussen online en offline delicten gevonden voor slachtofferschap. Uit deze analyses bleek dat meer factoren invloed hadden op de kans slachtoffer te zijn van beide soorten delicten (geslacht, leeftijd en armoederisico) dan van online delicten (geslacht en grootstedelijkheid). Slachtofferschap van offline delicten werd slechts door één risicofactor voorspeld (armoederisico). Wanneer werd ingezoomd op slachtofferschap van bedreiging werden meer effecten gevonden. Echter, in tegenstelling tot algemeen slachtofferschap werd gecombineerd slachtofferschap hier door het minst aantal factoren voorspeld. Terwijl alle onderzochte factoren enkel online en enkel offline slachtofferschap van bedreiging voorspelden, deden onderwijsvorm en leeftijd dit niet voor gecombineerd slachtofferschap. Daarenboven hadden onderwijsvorm, leeftijd en het schoollopen in een grootstad of niet en omgekeerd effect naargelang het type slachtofferschap.

Deze resultaten tonen aan dat er grote verschillen kunnen zitten tussen de verschillende vormen van slachtofferschap. Dit kan de afwezigheid van enkele verwachte significante effecten op offline slachtofferschap in het algemeen verklaren, en de verschillen tussen online, offline en gecombineerd slachtofferschap wanneer werd ingezoomd op bedreiging. In vorig onderzoek werden al verschillen gevonden tussen studies of delictsvormen (Bossler e.a., 2012; Reyns e.a., 2019), waardoor de nood aan het onderzoeken van risicofactoren per delictsvorm nogmaals benadrukt wordt.

\section{Beperkingen}

Deze studie is onderhevig aan een aantal beperkingen die in rekening moeten worden gebracht bij het interpreteren van de resultaten. Ten eerste werd online criminaliteit slechts beperkt bevraagd. Door het doel van de JOP-monitors kon een uitgebreide bevraging zoals in de jeugdcriminaliteitmonitor van het WODC niet. Daarenboven werden in de schoolmonitor - de data die werden gebruikt 
voor de risicoprofielen - enkel cyberdelicten in de brede zin bevraagd, niet in de enge zin. Een onderscheid hiertussen kon dus niet gemaakt worden, ondanks enige indicatie dat daders van gedigitaliseerde en cyberdelicten van elkaar verschillen (bijv. Rokven e.a., 2017). Om tot een beter beeld te komen van cyberdelinquentie onder jongeren is het belangrijk om meerdere delicten in zowel brede, zoals fraude in online shopping, als enge zin, zoals virussen verspreiden of ddos-aanvallen, te bevragen. Daarenboven kan hierin geopteerd worden om deze items gelijk te maken aan de vragen uit de jeugdcriminaliteitmonitor van het WODC, om vergelijkingen hiertussen te vergemakkelijken. Ten tweede waren interessante voorspellers gebaseerd op klassieke, criminologische theorieën (zoals zelfcontrole of routineactiviteiten, Grabosky, 2001) niet voorhanden in de data. Het kon dus niet worden nagegaan of deze factoren ook online delicten konden voorspellen. Ook de vragen rond delinquente vrienden waren enkel gebaseerd op offline feiten, waardoor de overlap tussen online delinquentie van vrienden en de kans om online delicten te plegen niet kon worden onderzocht. Tot slot is deze studie volledig gebaseerd op zelfrapportagecijfers. Over- of onderrapportage hierin is steeds mogelijk. Naast het verkeerd herinneren of interpretatieproblemen kunnen jongeren minder delicten aanduiden uit sociale wenselijkheid of uit angst voor bijvoorbeeld strafrechtelijke gevolgen, of meer om stoer over te komen. Vervolgonderzoek zou zelfrapportagecijfers kunnen aanvullen met officiele cijfers om een genuanceerder beeld te krijgen.

\section{Conclusie}

Als conclusie kan gesteld worden, in lijn met vorig onderzoek, dat de rapportage van online delicten relatief beperkt bleef vergeleken met offline delicten voor zowel dader- als slachtofferschap, alhoewel de prevalenties niet verwaarloosbaar zijn. Daarenboven blijkt dat de meeste daders en slachtoffers van online vormen ook respectievelijk dader of slachtoffer zijn van offline vormen. Een genuanceerder beeld komt naar voren als de verschillende delicten apart worden onderzocht, waarbij de ernst van het delict een rol speelt. Risicofactoren bleken te verschillen tussen de verschillende types daders, waarbij online daders het minst ernstige risicoprofiel hebben en daders van zowel offline als online delicten het meest ernstige. Dit is in lijn met vorig onderzoek (Rokven e.a., 2017). Voor slachtofferschap bleek uit de resultaten dat het belangrijk is om oog te hebben voor de verschillende delictsvormen.

\section{Literatuur}

Beerthuizen, M., Schouten, B., Rokven, J., Weijters, G. \& Laan, A. van der (2018). Verschillen in steekproeven verkregen via offline en online afnamemodi binnen de context van zelfrapportageonderzoek naar jeugddelinquentie. Tijdschrift voor Criminologie, 60(3), 352-364.

Bossler, A.M., Holt, T.J. \& May, D.C. (2012). Predicting online harassment victimization among a juvenile population. Youth \& Society, 44(4), 500-523.

Capeller, W. (2001). Not such a neat net. Some comments on virtual criminality. Social \& Legal Studies, 10(2), 229-242. 
CBS (Centraal Bureau voor de Statistiek). (2019). Digitale Veiligheid \& Criminaliteit 2018. Geraadpleegd op www.cbs.nl/nl-nl/publicatie/2019/29/digitale-veiligheidcriminaliteit-2018.

Cohen, L.E. \& Felson, M. (1979). Social change and crime rate trends. A routine activity approach. American Sociological Review, 44, 588-608.

Cops, D. (2014). Criminaliteit en onveiligheidsgevoelens doorheen de tijd. Een analyse op basis van 10 jaar JOP-monitor. In: L. Bradt, S. Pleysier, J. Put, J. Siongers \& B. Spruyt (eds.). Jongeren in cijfers en letters. Bevindingen uit de JOP-monitor 3 en de JOP-schoolmonitor 2013. Leuven: Acco, 68-90.

Donner, C.M., Jennings, W.G. \& Banfield, J. (2015). The general nature of online and offline offending among college students. Social Science Computer Review, 33(6), 663-679.

Gottfredson, M.R. \& Hirschi, T. (1990). A General Theory of Crime. Stanford, California: Stanford University Press.

Grabosky, P.N. (2001). Virtual criminality. Old wine in new bottles? Social \& Legal Studies, 10(2), 243-249.

JOP (Jeugdonderzoeksplatform). (2018a). Technisch verslag JOP-schoolmonitor 2018. Geraadpleegd op www.jeugdonderzoeksplatform.be/files/Technischverslag_JOPschoolmonitor_2018.pdf.

JOP (Jeugdonderzoeksplatform). (2018b). Technisch verslag JOP-monitor 4. Geraadpleegd op www.jeugdonderzoeksplatform.be/files/Technisch_verslag_JOPPostmonitor_2018.pdf.

Laan, A.M. van der, Beerthuizen, M.G.C.J. \& Weijters, G. (2016). Jeugdige daders van online-criminaliteit. Cahier Politiestudies 41(4), 145-168.

Leukefeldt, E.R., Domenie, M.M.L. \& Stol, W.Ph. (2010). Verkenning cybercrime in Nederland 2009. Den Haag: Boom Juridische uitgevers.

Martens, M. \& De Wolf, R. (2018). Measuring the Cost and Impact of Cybercrime in Belgium (BCC): D3.1.2 Risk Perception Monitor Report (2nd wave, 2017). Gent: imec-MICT, Ghent University.

Montiel Juan, I. (2016). Cibercriminalidad social juvenil: la cifra negra. IDP. Revista de Internet, Derecho y Politica, 22, 108-120.

Oksanen, A. \& Keipi, T. (2013). Young people as victims of crime on the internet. A population-based study in Finland. Vulnerable Children and Youth Studies, 8(4), 298-309.

Paoli, L., Visschers, J., Verstraete, C. \& Van Hellemont, E. (2018). The Impact of Cybercrime on Belgian Businesses. Mortsel: Intersentia.

Reep-van den Bergh, C.M.M. \& Junger, M. (2018). Victims of cybercrime in Europe. A review of victim surveys. Crime Science, 7(5), 1-15.

Reyns, B.W., Fisher, B.S., Bossler, A.M. \& Holt, T.J. (2019). Opportunity and self-control: do they predict multiple forms of online victimization? American Journal of Criminal Justice, 44, 63-82.

Rokven, J.J., Weijters, G. \& Laan, A.M. van der (2017). Jeugddelinquentie in de virtuele wereld. Een nieuw type daders of nieuwe mogelijkheden voor traditionele daders? (Cahier 2017-2). Den Haag: WODC.

Sahlqvist, S., Song, Y., Bull, F., Adams, E., Preston, J. \& Ogilvie, D. (2011). Effect of questionnaire length, personalization and reminder type on response rate to a complex postal survey. Randomized controlled trial. BMC Medical Research Methodology, 11, 62.

Stouthamer-Loeber, M., Loeber, R., Wei, E., Farrington, D.P. \& Wikström, P-O.H. (2002). Risk and promotive effects in the explanation of persistent serious delinquency in boys. Journal of Consulting and Clinical Psychology, 70(1), 111-123.

Vanhaeleweyn, B. \& De Marez, L. (2017). Imec.Digimeter 2017. Measuring Digital Media Trends in Flanders. Geraadpleegd op www.imec-int.com/digimeter. 
Wagen, W. van der, Zand-Kurtovic, E.G. van 't, Matthijsse, S.R. \& Fisscher, T.F.C. (2020). Cyberdaders: uniek profiel, unieke aanpak? Een onderzoek naar kenmerken van en passende interventies voor daders van cybercriminaliteit in de enge zin. Geraadpleegd op www.wodc.nl/binaries/2974_Volledige_Tekst_tcm28-426136.pdf.

Weulen Kranenbarg, M. (2018). Cyber-offenders versus Traditional Offenders. An Empirical Comparison (diss. Amsterdam). Geraadpleegd op https://research.vu.nl/en/ publications/cyber-offenders-versus-traditional-offenders-an-empirical-compari.

Weulen Kranenbarg, M., Holt, T.J. \& Gelder, J.-L. van (2019). Offending and victimization in the digital age. Comparing correlates of cybercrime and traditional offending-only, victimization-only and the victimization-offending overlap. Deviant Behavior, 40(1), 40-55.

Zebel, S., Vries, P. de, Giebels, E., Kuttschreuter, M. \& Stol, W. (2013). Jeugdige daders van cybercrime in Nederland. Een empirische verkenning. Enschede: Universiteit Twente/ NHL Hogeschool/Politieacademie/Open Universiteit. 